\title{
A DOUBLED DUCTUS PAROTIDEUS IN A COW
}

\author{
J. KAMAN \\ Department of Pathological Morphology and Parasitology, \\ University of Veterinary Science, 61242 Brno
}

Received February 3, 1984

\begin{abstract}
Kaman J.: A Doubled Ductus Parotideus in a Cow. Acta vet. Brno, 55, 1986: $3-9$;

A description is given of a bilateral, doubled ductus parotideus in a cow. This condition is hitherto unreported.

Both the dorsal and ventral branches of the parotid duct were equally and welldeveloped, passing in parallel but completely separated until just before their end. They united to form a single ductus parotideus only $2 \mathrm{~cm}$ (left side) and $2.5 \mathrm{~cm}$ (right side) before their piercing the buccinator muscle.

This rare deviation from the normal did not cause functional disturbance. The doubled duct caused only a slight change in the topography of the incisura vasorum facialium region; the author described this finding as a variation.

The origin of such a doubled duct was assumed to be embryonic, but the causal factor or factors were not investigated. It is hypothesized that this doubling was a result of doubling of an initial, proximal budding of the primordial gland duct.
\end{abstract}

Developmental variation, ductus parotideus, topography of incisura vasorum facialium, cattle.

Saliva is for the most species of great importance for the initial processing of feedstuffs. There is a relationship between the nature of feed and the morphology of salivary glands as discussed by $Z$ heden ov (1958). The structure of the salivary gland is ultimately translated into the chemical and physical composition and volume of saliva. Salivary glands are well-developed in herbivores consuming large amounts of relatively dry feeds. The development and maintenance of the structural integrity of the duct of the salivary gland is essential for the normal functioning of these glands.

The ductus parotideus of cattle is decribed as a single duct in textbooks of comparative and domesticated animal anatomy (E1lenberger and Baum 1943; Sisson 1947; Zhedenov 1958 and 1965; Schummer et al. 1973; Koch 1970; Najbrt et al. 1980) as well as in the bovine anatomy textbooks (McLeod et al. 1958). No mention is made of variation from this normal morphology for the ductus parotideus in cattle or in other domesticated animals except for the mention of the occurrence of an additional duct in the dog. In this species it is a short duct which drains an accessory parotid gland and empties directly into the distal aspect of the main duct; it is commonly bilateral (Miller et al. 1979).

The problem of anomalous ductus parotideus seems to be quite rare also in gross pathology textbooks (Nieberle and Cohrs 1970; Jubb and Kennedy 1970). Developmental defects may occasionally occur as congenital atresia of the duct in the dog but rarely in the horse and cattle (Zakrzewski 1962 in Joest 1962). The terminology and literature of veterinary teratology has been reviewed (Wiedeking 1969) and of 1085 citations, only one described an abnormal development of the parotid duct, a case of congenital atresia of the left ductus parotideus in a horse (Fowler 1965).

An extensive monograph on salivary gland diseases in man was published by Saza ma (1968) with general descriptions of diverticles, ectasia, stenosis, atresia and doubling. He found and described stenosis of both parotid ducts.

As no reports of a doubled ductus parotideus in cattle are known to this author and no mention is made to the condition in the detailed report of the morphology of and comprehensive literature 
review for salivary glands in the horse, cattle, and swine by Peters (1904), the following report is presented to document this condition.

\section{Materials and Methods}

This report is based on an observation of a bilateral ductus parotideus in a cow obtained from a municipal slaughterhouse as dissection material for students of veterinary medicine. The cow was estimated to be $2-2.5$ years of age, Czech Pied breed, in a good state of nutrition, and showed no signs of illness or pathology upon routine inspection.

The regio masseterica et buccalis was dissected with particular attention being paid to the ductus parotideus and the structures of the incisura vasorum facialium. Black and white photographs were prepared of these dissections.

\section{Results}

During a routine dissection of the left superficial aspect of the head of the cow, attention was focused to an unusual arrangement of the ductus parotideus. A more thorough dissection revealed the duct to be smaller in diameter than usual and that there was an additional duct. Dissection of these ducts along their entire course revealed a doubled ductus until about $2-2.5 \mathrm{~cm}$ from its opening into the oral cavity. The dissection was repeated on the right aspect of the head; there, too, was found a doubled ductus parotideus.

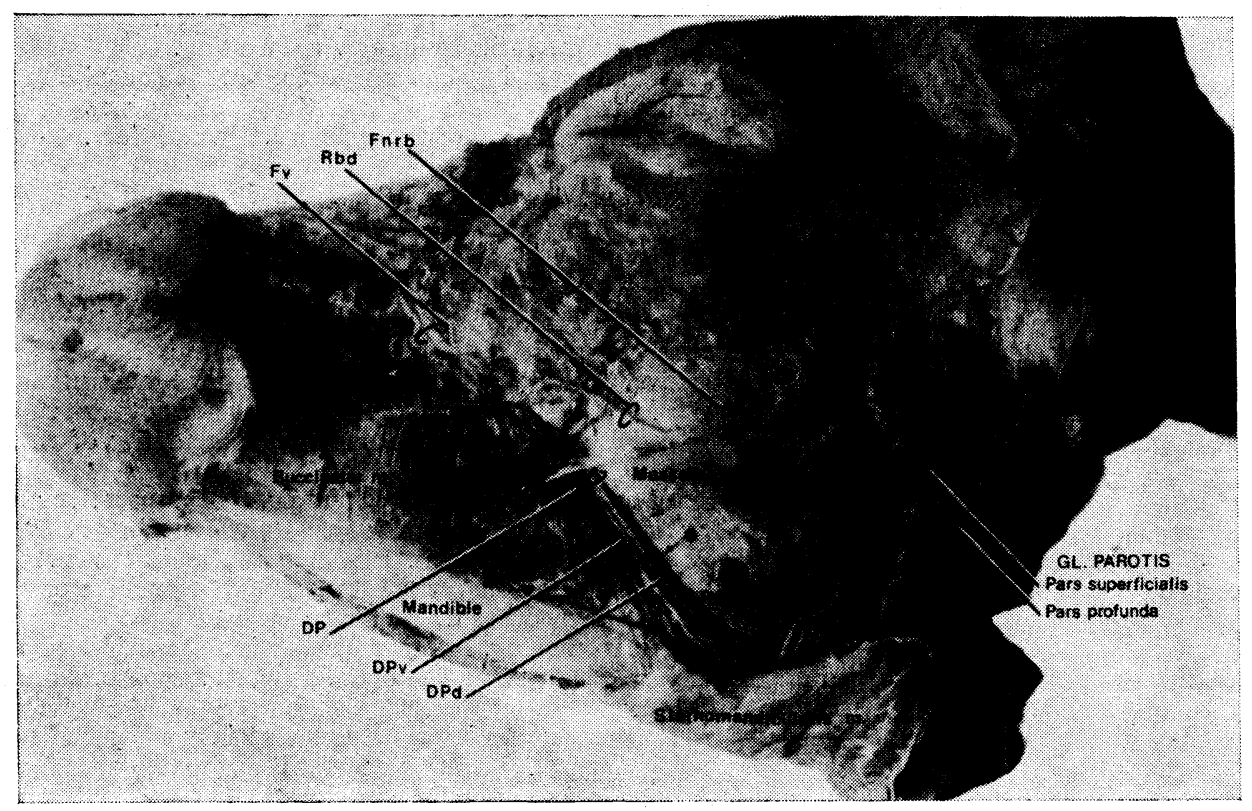

Fig. 1.

Superficial dissection, head of cow, left lateral aspect. Labelled are the pars superficialis et profunda of the Glandula parotis, Buccinator muscle, pars molaris, Masseter muscle, Sternocephalicus muscle, pars mandibularis, Mandible Fv - Facial vein, Rbd ramus buccalis dorsalis of facial nerve, DP ductus parotideus, common segment, DPv Ductus Parotideus ventralis, DPd Ductus Parotideus dorsalis, Fnrb Facial nerve, ramus buccalis. Asterisk with arrow indicates edge of black paper inserted to highlight structures of incisura vasorum facialium. 
The results of this dissection were preserved by photographs in Figs. 1, 2 and 3 . The parotid salivary gland was well-developed and somewhat larger than usual (Fig. 1). The elongated, club-shaped gland occupied the retromandibular fossa, i.e. the region bounded by the external acoustic meatus dorsally, the wing of the atlas and cleidomastoideus muscle caudally, and the ramus of the mandible and masseter muscle rostrally. Somewhat larger than usual, it extended rostrad, covering the parotid lymph node completely. Its overall shape conformed to the curvature of the caudal border of the ramus of the mandible, extending beyond the angle of the mandible and rostrally to a point midway along the broad insertion on the mandible of the superficial layer of the masseter muscle.

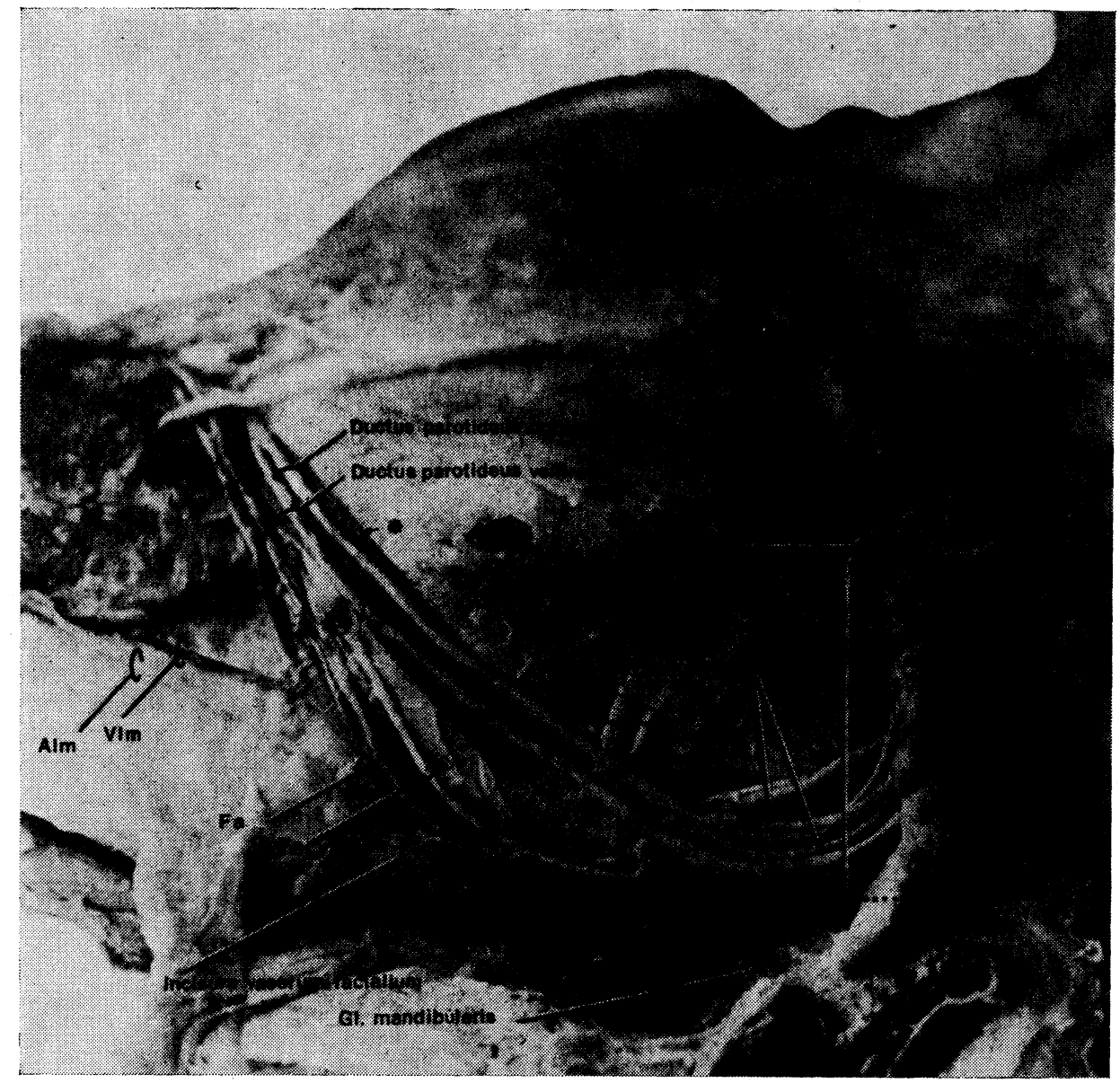

Fig. 2.

Superficial dissection of incisura vasorum facialium, head of cow, left lateral aspect. Labelled are the pars profunda of the Glandula parotis, Ductus parotideus dorsalis et ventralis, Ductuli glandulae, Incisura vasorum facialium, Glandula mandibularis. Alm arteria labialis maxillaris; VIm vena labialis maxillaris; Fa arteria facialis; Pn nervus parotideus; a, v arterial and venous branch to $\mathrm{m}$. masseter. Asterisk with arrow indicates adge of black paper inserted to highlight structures of incisura vasorum facialium. 
The dorsal projection of the gland into the retromandibular fossa was the largest; here it was $3.6 \mathrm{~cm}$ thick (medial to lateral) and $6.5 \mathrm{~cm}$ wide (rostral to caudal). The caudoventral part of the gland was conspicuously flattened and wedge-shaped; this ventral projection of the gland narrowed to only $11 \mathrm{~mm}$ in thickness. Medially the gland was broadly attached to the lateral surface of the mandibular salivary gland which was displaced somewhat caudally over the margin of the parotid gland.

From the craniomedial surface of the ventral half of the gland the interlobular ducts emerged (Fig. 3), soon converged, and fused to form, in this case, two gland ducts. This was the case for both the left and right sides of the head. The dorsal duct (Fig. 3, DPd) had its origin from the gland somewhat more dorsally that the

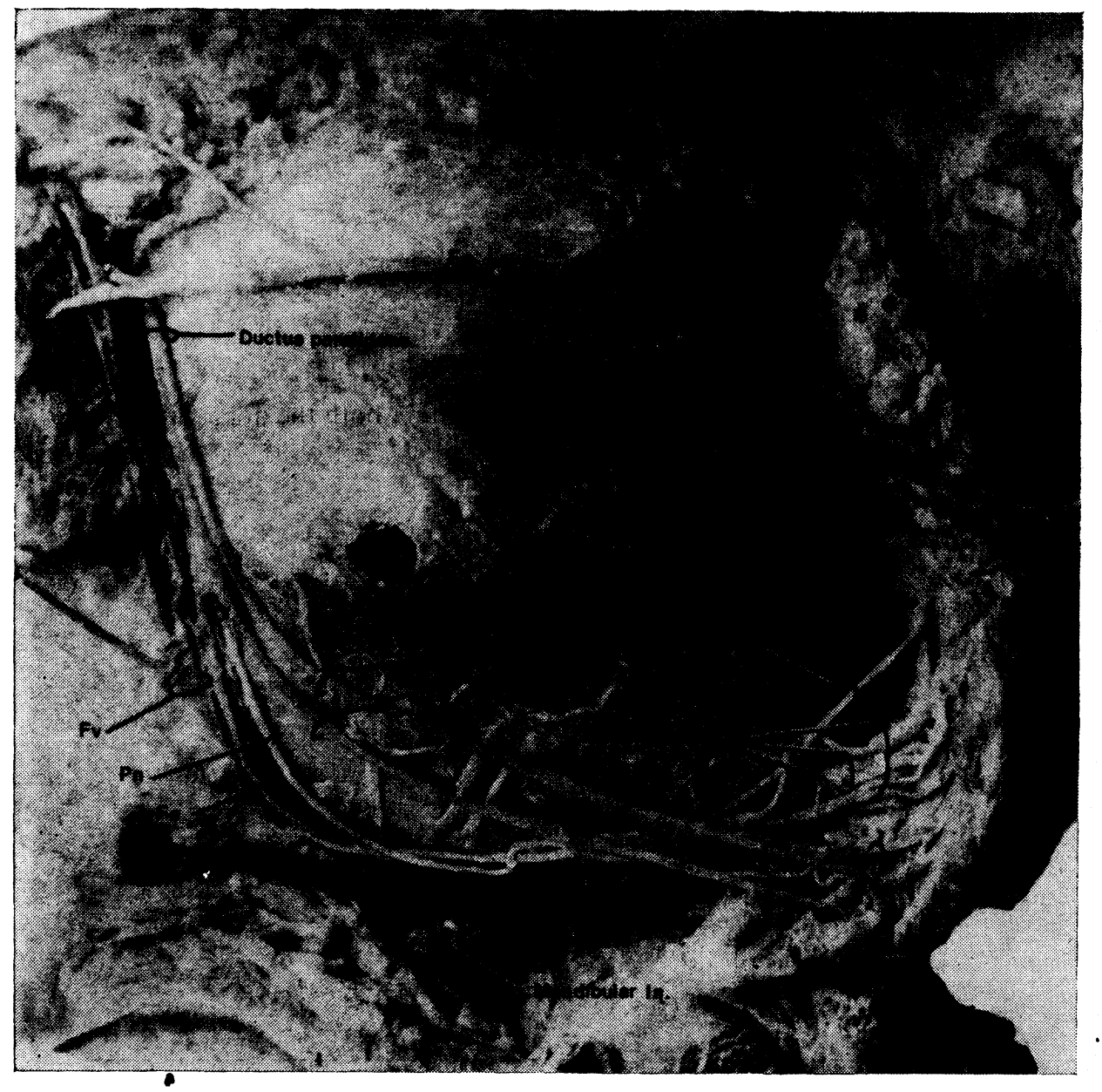

Fig. 3.

Dissection of ducts and ductuli of Glandula parotis, medial aspect, pars profunda, head of cow, left lateral aspect. Labelled are the Ductus parotideus, Ductuli glandulae and Mandibular lymph node. Fa Facial artery; Fv facial vein; Fn Facial nerve, ramus buccalis; Pn parotid nerve; DPd Ductus parotideus dorsalis; DPv ductus parotideus ventralis. Asterisk with arrow indicates probe retracting gland to expose medial aspect. 
ventral duct and was the larger of the two. This dorsal duct measured $3.5 \mathrm{~mm}$ in diameter and was formed by the confluence of three interlobular ductules. Two of these could in turn be traced to their origin, each from two smaller order ductules which anastomosed shortly after their emergence from a lobe of the glandular parenchyma. The third interlobular ductule arose from the gland more dorsally, from a point midway along the dorsoventral axis of the gland. It was formed by the convergence of three smaller order ductules which anastomosed very soon after their origin from the parenchyma of the lobule.

The ventral duct of the gland (Fig. 3, DPv) was formed by a connection of two interlobular ductules originating from the medial surface of the ventral aspect of the gland, only $3 \mathrm{~cm}$ from its ventralmost projection. One of these ductules was formed by the confluence of two ductules of smaller order; the other was a direct continuation from the gland parenchyma.

Both of these parotid duct branches coursed in parallel along the ventral margin of the mandible, adjacent to the broad insertion of the superficial part of the masseter muscle (Figs. 1, 2,3). The ducts then followed the curvature of the ventrorostral margin of the masseter muscle (Fig. 1). Approximately $1.5 \mathrm{~cm}$ before the perforation of the ducts into the buccinator muscle, the ducts fused (Fig. 2, 3). The continuation as a single ductus parotideus was about $2 \mathrm{~cm}$ in length and it deviated slightly rostrad from the line of the rostral margin of the masseter. The duct attained the buccinator muscle at its pars molaris, pierced the muscle (Fig. 1,2) and terminated in the oral cavity on the papilla parotidea at the buccal mucosa adjacent to the interdental space between molar teeth 1 and 2 .

During their passage in the incisura vasorum facialium, both the dorsal and ventral parotid ducts were related to other structures as follows: rostralmost was the arteria facialis, then the vena facialis, the ventral branch of the ductus parotideus, the dorsal branch of the ductus parotideus, and the nervus parotideus. The latter lay more medial than caudal to both branches of the parotid duct.

Findings from dissection of the right side of the head were similar, the only difference being that the two ducts fused somewhat more proximal to the gland, i.e. $2.5 \mathrm{~cm}$ before passage of the common duct through the buccinator muscle.

\section{Discussion}

A description of a bilateral, doubled ductus parotideus is presented as a case report. No mention of this condition in any of the domesticated animals was found in the literature surveyed.

The seeming rarity of this condition may accurately reflect its infrequency or it may reflect the fact that the area is infrequently dissected in detail in the anatomy laboratory as is also the case for the dog and the horse. It is infrequently inspected at slaughter. Furthermore, this deviation from normal may escape detection because it does not cause functional disturbance. Despite this marked morphological variation in the ductus parotideus, no functional disturbances are to be expected, as with stenosis or sialoliths, which would alter the flow of saliva. Therefore this deviation would not normally be included among pathological changes. It is properly classified as a developmental variation.

The parotid salivary gland originates as a simple budding of oral ectoderm from the dorsolateral margins of the stomodeum (Zietzschmann 1924; Patten 1959; Michel 1972) penetrating caudad from the oral cavity through the mesenchymal anlage of the face. Ventral to the ear primordium it divides to form the primordial gland cords. The anlage gradually luminizes and differentiates into its secretory and 
duct parts. Proposing a slight variation of this commonly described pattern of development, Stanek (1962) has described that proximally the salivary gland duct primordium is groove-shaped and then closes to form a tube. According to Zietzschmann (1924) the primordium of the glandula parotis in cattle can be found as early as in the $22 \mathrm{~mm}$ embryo.

Embryologists and anatomists are generally agreed that a smaller duct may arise from the main duct, giving rise to the ductus parotideus accessorius which in turn gives rise distally to the glandula parotis accessoria as a definitive structure that may be found also in the adult (Zietzschmann 1924; Stanek 1962; Miller et al. 1979).

The observations upon which this report is based would seem to argue against this being an accessory parotid gland lobe. The accessory lobe is usually only rudimentary, formed by a single or a small number of lobules with a correspondingly small duct. Such an accessory gland is usually attached to the glandula parotis, but it can be dislocated rostrally to a varying degree. In the specimen described the glandula parotis was formed as a single body and the overall size did not vary beyond the normal morphological range. Further, the duct of the accessory parotid gland is short and enters the main duct after only a short course. In the case described herein, both the dorsal and ventral ducts on each side were essentially equal in size and equal in length and continued as such until very near their termination in the oral cavity. As a consequence, it was assumed that the origin of this doubled ductus parotideus could be traced to its development and a premature branching, i.e. topographically its initial normal branching did not occur ventral to the ear primordium but shortly after its penetration into the mesenchymal anlage of the face. From the present material no reason for such a premature branching can be detected.

\section{Zdvojený ductus parotideus u skotu}

$\mathrm{V}$ př́íspěvku se pojednává o ojedinělém, $\mathrm{v}$ literatuře nepopsaném, oboustranně zdvojeném ductus parotideus u dospělého skotu. Ductus parotideus byl rozdělen téměř $\mathrm{v}$ celém průběhu. Jak jeho dorzální, tak i ventrální složka vystupovaly samostatně již $\mathrm{z}$ glandula parotis, probíhaly téměř $\mathrm{v}$ celém rozsahu ductus parotideus vedle sebe a spojily se v jednotný vývod teprve $1,5 \mathrm{~cm}$ vlevo a $2,5 \mathrm{~cm}$ vpravo před vstupem do musculus buccinator. Obě složky ductus parotideus byly prakticky rovnocenně vyvinuty.

Popsaná vývojová odchylka nepůsobila funkční poruchy, jen poněkud měnila topografický obraz, zejména $\mathrm{v}$ incisura vasorum facialium, a je proto hodnocena jako variace. Její vznik spadá do časného embryonálního údobí. V diskusi se vyslovuje hypotéza, že $\mathrm{k}$ ní došlo předčasným rozvětvením vývojového základu glandula parotis. Vlastní př́čina této anomálie je nejasná.

\section{Удвоенный ductus parotideus у крупного рогатого скота}

Приводится описание в литературе до сих пор не встречающегося удвоения выводного протока околоушной железы у крупного рогатого скота. Данный проток удвоен двусторонне. Обе компоненты (pars dorsalis и pars ventralis) были одинаково развиты и преимущественно проходили параллельно, но полностью отделенно, соединяясь лишь $1,5 \mathrm{~cm}$ налево и 2,5 cм направо перед входом в $\mathrm{m}$. buccinator в единый ductus parotideus. Приведенное отклонение не вызвало функциональных нарушений, изменило лишь топографическую ситуацию в incisura vaso- 
rum facialium; автором оно оценивается как вариант, хотя и весьма редкий.

Возникновение удвоенного ductus parotideus относится $\mathrm{k}$ раннему эмбриональному развитию. В обсуждении высказана гипотеза, что данная аномалия произошла в результате преждевременного разветвления эволюционной основы glandula parotis.

\section{References}

ELLENBERGER, W. - BAUM, H.: Handbuch der vergleichenden Anatomie der Haustiere. Springer-Verlag, Berlin, 1943.

FOWLER, M. E.: Congenital atresia of the parotid duct in a horse. J. Am. Vet. Med. Ass., 146, 1965: 1403-1404. In Wiedeking, J. F., 1969.

JUBB, K. V. F. - KENNEDY, P. C.: Pathology of domestic animals. 2nd ed. Vol. 1, Academic Press., New York - London, 1970.

KOCH, T.: Lehrbuch der Veterinär-Anatomie. Bd. II., VEB G. Fischer, Jena, 1970.

McLEOD, W. M. - TROTTER, D. M. - LUMB, J. W.: Bovine Anatomy. 2nd. ed. Burgess, Minneapolis, MN, 1958.

MICHEL, G.: Kompendium der Embryologie der Haustiere. VEB G. Fischer, Jena, 1972.

MILlER, M. E. - CHRISTENSEN, G. C. - EVANS, H. E.: Anatomy of the Dog. W. B. Saunders Company, Philadelphia - London, 1968.

NAJBRT, R. et al.: Veterinary Anatomy 1. SZN, Praha, 1980 (in Czech).

NIEBERLE, COHRS, P.: Lehrbuch der speziellen pathologischen Anatomie der Haustiere. VEB G. Fischer, Jena, 1961.

PATTEN, B. M.: Human embryology. Medgiz, Moskva, 1959 (Russian translation).

PETERS, J.: Untersuchungen über die Kopfspeicheldrüsen bei Pferd, Rind und Schwein. Inaug. Diss., Med. Fak., Giessen, 1904.

SAZAMA, L.: Poruchy Stenonova vývodu. Ceskoslov. Stomatol., 65, 1965: 352-358.

SAZAMA, L.: Nemoci slinných žláz. SZN, Praha, 1968.

SCHUMMER, A. - NICKEL, R. - SACK, W. O.: The Viscera of the Domestic Mammals, 2nd ed. P. Parey, Berlin, 1979.

SISSON, S.: The Anatomy of the Domestic animals. W. B. Saunders Company, Philadelphia - London, 1947.

STANEK, I.: Embryológia človeka. SAV, Bratislava, 1962.

WIEDEKING, J. F.: Terminologie der embryonalen Entwicklungsstörungen - zugleich Bibliographie neuerer Literatur auf dem Gebiet der Teratologie in der Veterinär-medizin. Inaug. Diss., Giessen, 1969.

ZAKRZEWSKI, A.: Mund - und Rachenhöhle mit Speicheldrüsen. In JOEST, E.: Handbuch der speziellen pathologischen Anatomie der Haustiere. P. Parey, Berlin - Hamburg, 1962.

ZIETZSCHMANN, O.: Lehrbuch der Entwicklungsgeschichte der Haustiere. R. Schoetz, Berlin, 1924.

ZHEDENOV, V. N.: Obščaja anatomija domašnich životnych. Sovětskaja nauka, Moskva, 1958.

ZHEDENOV, V. N.: Anatomija domašnich životnych II. Splanchnologija. Vysšaja škola, Moskva, 1965. 